\title{
1 Spatial pattern of invasive and native graminoids in the Brazilian cerrado
} 2

3 Pavel Dodonov ${ }^{1,2^{*}}$, Karen A. Harper ${ }^{3}$, Rafael de Oliveira Xavier ${ }^{2,4}$, Dalva M. Silva Matos²

$4{ }^{1}$ Institute of Biology, Federal University of Bahia, Rua Barão de Jeremoabo, 668, Ondina - Salvador, BA, 40.170-

5 115, Brazil.

$6{ }^{2}$ Ecology and Conservation Lab, Department of Hydrobiology, Federal University of São Carlos, São Carlos, SP,

7 13.562-180, Brazil

$8{ }^{3}$ Biology Department, Saint Mary’s University, Halifax, NS B3H 3C3, Canada.

$9{ }^{4}$ Biosciences Institute, University of São Paulo, Rua do Matão, 321, São Paulo, SP, 05508-090, Brazil.

10 *Corresponding author. e-mail: pdodonov@gmail.com; (+55) (73) 99172-4279

\section{1}

12 Abstract

13 Invasive grasses are an important threat in tropical savannas and grasslands and may be affected 14 by natural and anthropogenic features of the environment. They may affect native species at a 15 variety of scales, but a spatially-explicit assessment of their effects is lacking. We studied the 16 spatial pattern of native and invasive graminoids in Brazilian cerrado in southeastern Brazil and 17 assessed the effects of vegetation type, elevation and edges. We sampled native grasses, native 18 sedges, and two invasive grass species (Urochloa decumbens and Melinis minutiflora) along 19 three 301 to 1334 m-long transects encompassing grassland, forest, and savanna. We used 20 wavelet transforms, generalized additive models, and null model simulations for analysis.

21 Invasive grasses were mostly found in open vegetation. Neither native nor invasive species were 22 consistently affected by elevation or edges. Much of the spatial variation could be explained by 23 small-scale autocorrelation, but $M$. minutiflora had a more heterogeneous pattern than $U$.

24 decumbens. Invasive grasses were negatively related to native ones at a variety of scales, from 1 25 to $66 \mathrm{~m}$, and we observed both positive and negative relations between the two invasive species, 26 with positive ones a finer scales. We hypothesize that spatial pattern characteristics of different 27 invasive species may be related to their invasion potential.

28 Keywords: Bivariate wavelets, edge influence, Melinis minutiflora, Urochloa decumbens, 29 wavelet transform.

\section{Introduction}

31 Plant communities have intrinsic spatial heterogeneity, described by their spatial pattern (Dale 
32 1999), with alternating high-cover areas (patches) and low-cover areas (gaps); the distance 33 between the centers of adjacent patches and gaps is the scale of spatial pattern (Dale 1999). 34 Spatial pattern may be related to competition (Wiegand et al. 2005; Strand et al. 2007), soil 35 properties (Ruggiero et al. 2002; Chudomelová et al. 2017), disturbances (Strand et al. 2007), 36 edges (Harper et al. 2018), and vegetation type, and affects species coexistence and hence 37 biodiversity (Durrett and Levin 1998; Stoll and Prati 2001; Tilman 1994). Intraspecific 38 aggregation (resulting in a more patchy structure) may promote species coexistence, especially 39 where environmental conditions are temporally stable and spatially heterogeneous (Chesson 40 2000; Snyder and Chesson 2003).

41 Spatial pattern is an important aspect of biological invasions (Travis and Park 2004; Petrovskaya 42 et al. 2017). Invasive plants often show scales of spatial pattern of a few meters to tens of meters 43 (Chapman et al. 2015, Shields et al. 2015), possibly affecting the spatial pattern of plant 44 communities as a whole. This may be related to many factors, including topography (Jeltsch et 45 al. 1998; Augustine 2003; Ashton et al. 2016) and disturbances (D'Antonio and Vitousek 1992; 46 Dodonov et al. 2013). Topography may affect invasive plants through local variation in water 47 availability in the upper soil layer, a key factor for invasive plants such as grasses (Gibson and 48 Hulbert 1987; Scholes and Archer 1997). Linear disturbances, including roads and trails, may 49 serve as dispersion corridors (LaPaix et al. 2012; Bacaro et al. 2015) and environmental 50 conditions at their edges may facilitate the establishment of invasive plants (Morgan 1998; 51 Cilliers et al. 2008; Dodonov et al. 2013).

52 Invasive grasses impact biodiversity in different ecosystems worldwide (D'Antonio and Vitousek 53 1992; Pivello et al. 1999a; Rossiter-Rachor et al. 2009) and may dominate tropical grasslands 54 and savannas, seriously impacting native species (Pivello et al. 1999a, b; Hoffman and Haridasan 55 2008; Almeida-Neto et al. 2010; MacDonald 2004). Invasive grasses often show intraspecific 56 aggregation and form dense mats, hampering other species (D'Antonio et al. 2011), and 57 characterizing their spatial pattern in patchy environments may aid in understanding grass 58 invasions. Savannas are naturally patchy, with alternating areas of high and low woody cover and 59 corresponding low and high herbaceous cover (Jeltsch et al. 1998), and are thus an interesting 60 model to study the spatial pattern of invasive grasses in a patchy environment. We studied how 61 invasive and native grasses are related to vegetation type, natural topographic variation, and 
62 anthropogenic linear disturbances by quantifying their spatial pattern in a highly heterogeneous 63 environment, the Brazilian cerrado. Invasive grasses can impact cerrado plant communities by 64 suppressing native graminoids (Damasceno et al. 2018; Pivello et al. 1999a, b), hampering the 65 regeneration of woody species (Almeida-Neto et al, 2010; Hoffmann et al, 2008), and changing 66 local disturbance regimes (Gorgone-Barborsa et al, 2005; Hoffmann et al. 2012). Our specific 67 objectives were 1) to compare the cover and spatial pattern of native and invasive graminoids 68 among vegetation types (grassland, savanna, and forest with different disturbance histories), 2) to 69 assess the effects of topography and anthropogenic linear disturbances on these graminoids (by 70 relating their pattern to the topographic gradient and to the proximity of linear disturbance 71 edges), and 3) to assess the relationships of invasive grasses with each other and with native 72 graminoids at different scales. We hypothesized that 1) invasive grasses would be more abundant 73 and be spatially structured at larger scales in the more open and disturbed vegetation types, with 74 the opposite trends for native species; 2) the cover of invasive grasses would decrease up to a 75 certain distance from edge whereas that of native graminoids would increase (Dodonov et al. 76 2013, Mendonça et al. 2015); and 3) there would be negative relationships in the cover of 77 invasive and native graminoids and of different invasive grasses (Damasceno et al. 2018; Pivello 78 et al. 1999a,b) at a variety of spatial scales.

\section{Methods}

\section{Study sites}

81 We sampled two areas in São Paulo state, southeastern Brazil: Itirapina Ecological Station

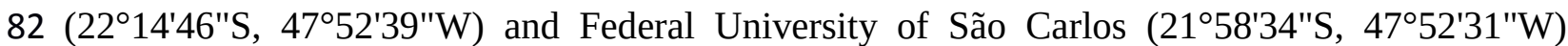
83 (Figure 1a-d). These sites were selected because they were easily accessible and spatially 84 heterogeneous on a small scale. The vegetation types in these sites include riparian forests, 85 savanna known as typical cerrado, open savannas known as campo sujo, and grasslands 86 (classification according to Coutinho 1978; Ribeiro and Walter 2008). Graminoids account for 30 87 to $90 \%$ of the biomass in these grasslands and savannas (Kauffman et al. 1994).

88 Itirapina Ecological Station is mostly occupied by campo sujo, often associated with a shallow 89 water table in this area (Leite et al. 2018), gallery forests, savanna-forest ecotones, and degraded 90 campo sujo areas occupied mostly by African grasses (Figure 2a, c, f). The creation of Itirapina 91 Ecological Station began in 1957 and was completed in 1984 (Zanchetta et al. 2006). The area 
92 has a long history of human impacts prior to becoming a protected area (pers. comm. from the 93 station's employees) and the station's most recent management plan states that nearly all 94 grassland and savanna areas therein contain African grasses (Zanchetta et al. 2006). The area in 95 São Carlos was previously occupied mostly by eucalypt plantations and pastures, which were 96 removed between 1972 and 1988 (Fushita et al 2017). Currently, this area contains degraded 97 campo sujo dominated by African grasses, typical cerrado in intermediate and advanced states of 98 regeneration, riparian forests and savanna-forest ecotones (Figure 2b, d, e, g, h). Invasion by 99 African grasses in this area possibly began in the 1960s (Marcelo Nivert, pers. comm.). The 100 predominant soils are oxisols and entisols in Itirapina (Reis and Zanchetta 2006) and dystrophic 101 oxisols in São Carlos (Dantas and Batalha 2011). The climate is humid subtropical in both areas, 102 with an annual precipitation of around $1400 \mathrm{~mm}$ and an average annual temperature of around 103 220C (Oliveira and Batalha 2005; Reis and Zanchetta 2006). A large part of the study site in São 104 Carlos was hit by a dry-season fire in August 2006; we are unaware of more recent fires affecting 105 our sampling locations, and the sampling locations in Itirapina have been protected from fire for 106 at least $15-20$ years..

107

\section{Sampling}

109 We located one transect in Itirapina (transect I1, 733 m long) and two in São Carlos (transects S1 110 and S2, 1334 and $301 \mathrm{~m}$ ) (Figure 1). Transects I1, S1 and S2 were sampled, respectively, 111 between September 2012 - February 2013, August 2011 - August 2012, and March - August 112 2014. To avoid confouding seasonal variation with spatial pattern along the longest transect, we 113 sampled it non-sequentially, e.g. started sampling at its middle rather than at one extremity. The 114 transects traversed different vegetation types (Table 1, Figure 2), and anthropogenic linear 115 disturbances, mostly narrow firebreaks (that also act as forest roads), and were placed 116 subjectively to maximize the variation in vegetation types and the number of firebreaks. Total 117 variation in altitude was 15, 26.5, and $8 \mathrm{~m}$ along I1, S1, and S2, respectively (Figure 1e-g). 118 Transect I1 traversed degraded campo sujo, campo sujo, an ecotone, and riparian gallery forest. 119 Transect S1 traversed typical cerrado (intermediate and advanced regeneration) and degraded 120 campo sujo. Transect S2 included typical cerrado, riparian gallery forest, and ecotone. Each 121 transect crossed 4-5 narrow linear disturbances (5-20 m-wide), resulting in a total of 24 edges 122 along three transects (Table 1). 
123 We sampled graminoids along each transect using $1 \times 1 \mathrm{~m}$ contiguous quadrats . Contiguous 124 quadrats permit the detection of spatial patterns at different scales, enabling a thorough 125 assessment of spatial variation in the response variables (Xiaobing and van der Maarel 1997; 126 Dale 1999). Within each quadrat, we visually estimated the cover of four graminoid types: two 127 species of invasive grasses (Urochloa decumbens (Stapf) R.D.Webster and Melinis minutiflora P. 128 Beauv - Poaceae), native grasses (Poaceae), and native sedges (Сyperaceae). U. decumbens and 129 M. minutiflora are C4 African grasses (Klink and Joly 1989) and are considered serious threats to 130 cerrado vegetation (Hoffmann and Haridasan 2008; Xavier et al. 2017). U. decumbens usually 131 forms a continuous cover, whereas M. minutiflora tends to have a patchy distribution (Pivello et 132 al. 1999b). We did not differentiate native grasses from other exotic but non-invasive grasses 133 (e.g. Melinis repens (Willd.) Zizka) because these exotic species occur with low frequency and 134 are not considered a conservation threat in the cerrado (Xavier et al. 2017, Xavier et al. 2019). 135 We had six cover classes: 0\%, 0 - 12.5\%, 12.5 - 25\%, 25 - 50\%, $50-75 \%$, and $75-100 \%$, and 136 used their mid-points in the analyses.

\section{Data analysis}

138 We analyzed each graminoid group along each transect separately for all analyses. The scales of 139 spatial pattern (see below) were always determined for the full transects and for each vegetation 140 type individually. For the first objective (comparing graminoids among vegetation types), we 141 assessed the frequency, average cover, and scales of spatial pattern in each vegetation type. We 142 calculated the frequency (proportion of quadrats containing each graminoid type) and average 143 cover (excluding zero-cover quadrats, as they were already considered in the frequency 144 calculation) and compared these values to a null model representing homogeneous vegetation 145 along the transects. For this, we calculated two-tailed 95\% confidence intervals for a first-order 146 Markov chain (MC1) model including spatial autocorrelation but assuming there are no 147 differences among the vegetation types; we used MC1 because complete spatial randomness is 148 usually an ecologically unrealistic null model (Fortin and Jacquez 2000, James et al. 2010). In 149 our MC1 model, the cover of a graminoid in a quadrat is a stochastic function of its cover in the 150 adjacent quadrat, as calculated from the data (Dodonov 2015; Online Resource 1), representing 151 small-scale dispersal especially by vegetative spread. We simulated the data by 1) selecting a 152 random position along the transect, 2) assigning the cover of the graminoid in question in a 153 random quadrat to the selected position, 3) randomly determining the cover in the next quadrat 
154 based on the current quadrat's cover, and 4) repeating step 3 until reaching the end of the transect 155 (Dodonov 2015). This procedure was applied in both directions, i.e. towards the end and the 156 beginning of the transect, 4999 times, resulting in 5000 datasets for each response variable along 157 each transect (the observed data and 4999 simulations, Manly 2007).

158 We used wavelets (Percival and Walden 2000; Dong et al. 2008; Rouyer et al. 2008) to assess the 159 scales of spatial pattern (which can be understood as the average distance between patch and gap 160 centers - Dale 1999), up to a maximum scale of $75 \mathrm{~m}$. We used the continuous wavelet 161 transform (CWT), a highly redundant transformation of the data that shows its adjustment to a 162 wavelet template at contiguous scales of $1,2 \ldots j$ meters, where $j$ is the maximum scale examined. 163 This is done by multiplying the graminoid cover data by the wavelet template centered at the first 164 position, then at the second position, and so on until the last position along the transect. The 165 wavelet template is then expanded and this analysis is repeated for a larger scale. The result 166 shows how similar the signal is to the shape of the wavelet template at each position along the 167 transect at different scales, and thus depends on the wavelet template used (Percival and Walden 168 2000; Dong et al. 2008; Rouyer et al. 2008). The amount of variation at each scale, or scale 169 variance, is calculated by squaring the CWT coefficients and averaging the squared values across 170 all positions for a given scale (Dale and Mah 1998; Rosenberg and Anderson 2011).

171 We calculated scale variance based on the Mexican Hat wavelet, a second derivative of a 172 Gaussian function (Dale and Mah 1998; Percival and Walden 2000), for scales up to $75 \mathrm{~m}$, 173 except when limited by the number of quadrats or by their proximity to the transects' limits. For 174 this wavelet template, maximum variance values are observed at scales at which the template 175 overlaps high-cover areas (patches) surrounded by low-cover areas (gapes) or vice-versa. We 176 assessed significance by comparing the variance at each scale with one-tailed 95\% confidence 177 intervals for the MC1 models. As the differences among vegetation types in graminoid frequency 178 and cover were assessed in the previous analysis, we simulated MC1 models separately for each 179 vegetation type. Thus, the null hypothesis was that the spatial pattern within each vegetation type 180 is determined by small-scale autocorrelation, but there may be other differences among 181 vegetation types (Dodonov 2015). As above, we used 4999 simulated datasets plus the original 182 data.

183 For the second objective (assessing effects of edges and topography), we adjusted, for each 
184 transect, binomial generalized additive models with logit link functions (GAMs - Zuur et al. 185 2009) relating the cover of each graminoid type to either either distance to the nearest firebreak 186 or elevation and including vegetation type in all models, resulting in a total of 24 GAMs. We 187 included vegetation type to avoid confounding differences among vegetation types with effects 188 of other explanatory variables, as, for example, forest vegetation was farther from edges and on 189 lower ground than other vegetation. Quadrats on linear disturbances were excluded because we 190 were interested in determining how edge distance affects the remaining vegetation. The optimal 191 degree of smoothing was determined by cross-validation, but we set a maximum limit of 5 192 effective degrees of freedom to avoid overfitting (Zuur et al. 2009).

193 We calculated the significance of each GAM by comparing them to MC1 models considering 194 spatial autocorrelation and differences among the vegetation types, as above. We adjusted the 195 two GAMs for each simulated dataset, extracted the proportion of deviance explained by the 196 model (analogous to an $\mathrm{R}^{2}$ ), and calculated one-tailed significance as the proportion of simulated 197 datasets in which the proportion of explained deviance was at least as great as that obtained for 198 the original data.

199 For the third objective (assessing the relationships between native and invasive graminoids), we 200 used wavelet scale covariance, also known as bivariate wavelet analysis, to assess the 201 relationship between invasive and native graminoids and between the two invasive species 202 (Hudgins and Huang 1996; Rosenber and Anderson 2011). Wavelet scale covariance is calculated 203 by multiplying the CWT coefficients of two response variables and calculating the average of 204 this product across all positions for each scale (Rosenberg and Anderson 2011); the result shows 205 at which scales the two response variables are positively or negatively correlated. We used the 206 Mexican hat wavelet and a maximum scale of 75 m, as above. We calculated 95\% confidence 207 intervals based on MC1 models as in the previous analysis, using one-tailed confidence intervals 208 for the relationships between invasive and native graminoids to focus on negative relations only 209 and two-tailed intervals for the relations between the two invasive species.

210 All analyses were performed in R 3.2.3 (R Core Team 2015), with the packages wmtsa 211 (Constantine and Percival 2012) for wavelet analyses and mgcv (Wood 2011) for GAMs. 212 Pseudocode for the MC1 models is available as Online Resource 1. The datasets and the full R 213 code used, including functions for the MC1 simulations and for wavelet variance and covariance, 
214 are available as Online Resource 2 and 3, respectively.

\section{Results}

216 The frequency and cover of the different graminoid types varied among transects and vegetation

217 types (Figure 3, Tables 2 and 3). The cover of $U$. decumbens was lower than predicted by the 218 MC1 models (i.e. lower than would be expected if spatial autocorrelation alone determined its 219 cover) in some campo sujo and typical cerrado areas, but it was more frequent and had higher 220 cover than predicted in degraded campo sujo. Cover and frequency of $M$. minutiflora generally 221 did not deviate from the MC1 models. Native grasses were less frequent than predicted by the 222 MC1 models in degraded campo sujo (Tables 2 and 3). U. decumbens and M. minutiflora were 223 completely or nearly absent from ecotones in Itirapina and from forest areas. Native sedges were 224 absent from the degraded campo sujo areas in São Carlos. Otherwise, all graminoids were found 225 in all vegetation types along all transects.

226 There were few significant scales of spatial pattern (i.e. deviations from the MC1 model 227 predictions); larger scales, over 30-40 m, were predominant and no scales were significant for 228 transect S2 (Table 4). U. decumbens had significant scales of approx. 10-13 and 40-55 m in 229 degraded campo sujo. Scales of pattern were significant for M. minutiflora only for transect S1, 230 with scales of $40-75 \mathrm{~m}$ in all vegetation types and an additional scale of 16-17 $\mathrm{m}$ in degraded 231 campo sujo. Native grasses showed significant scales of 22 to $75 \mathrm{~m}$ depending on the vegetation 232 type. Smaller scales, of 17-51 m, were observed for native sedges.

233 Effects of edges and topography were minimal, with only five significant or marginally 234 significant relations $(\mathrm{p}<0.08)$. $U$. decumbens and native grasses had maximum cover at 235 intermediate elevation at some transects ( $<<0.07$; Figure 4 a-c). Sedge cover increased slightly 236 with distance from the edge whereas native grass cover was greatest at intermediate distances 237 along one transect each (Figure 4 d-e).

238 Negative relationships between invasive and native graminoids were observed along all transects 239 and in most vegetation types, with finer scales being dominant for M. minutiflora (Table 5). 240 Negative relationships between $U$. decumbens and native grasses were observed at scales of 1,5241 13, and 19-66 m. Those between $U$. decumbens and native sedges were less common, but were 242 also observed at scales of 1, 11-22 and 69-75 m. M. minutiflora was negatively related to native 
243 grasses at scales of 1-18 and 36-66 m, and to native sedges at scales of 1-4 and 23-46 m. The two 244 invasive grasses were largely uncorrelated with each other (Table 6), but positive relationships 245 were observed at scales of 2-10, 41-51 and 66-75 m, and negative ones at scales of 1-2 and 12-18 $246 \mathrm{~m}$

\section{Discussion}

248 Vegetation type affected both native and invasive graminoids. Both study sites had a substantial 249 cover of invasive grasses, but these species were rare or absent in forests. This is consistent with 250 the environmental constraints associated with these vegetation types, as $U$. decumbens and $M$. 251 minutiflora may be more limited by shade than native graminoids (Xavier et al. 2017). Likewise, 252 both invasive grasses were absent from ecotones in the Itirapina transect, which are transitions 253 between wet grasslands and riparian forests dominated by floodplains species (pers. obs.). The 254 hydrological regime may explain the absence of invasive grasses in these sites (Xavier et al. 255 2017), even though M. minutiflora, unlike U. decumbens (Dias-Filho and Carvalho 2000), is 256 moderately resistant to waterlogging periods (Xavier et al. 2017). The extensive variation within 257 the expected range for the MC1 models shows the high importance of small-scale autocorrelation 258 in this system.

259 Spatial patterns also differed between the invasive grasses: $M$. minutiflora tended to occur in 260 clumps, unlike the more continuous cover of $U$. decumbens, as has also been observed 261 previously (Pivello et al. 1999b). M. minutiflora produces many wind-borne seeds (Martins et al. 262 2009) and is stress-tolerant (Baruch and Jackson 2005; Xavier et al. 2017; Xavier and D'Antonio 263 2017). Dispersal ability is closely related to spatial dynamics and persistence of species in patchy 264 environments (Hassell et al. 1994), such as Neotropical savannas (Jeltsch et al. 1998; Gonçalves 265 and Batalha 2011; Dodonov et al. 2014b). We hypothesize that a synergism between effective 266 seed dispersal and phenotypic plasticity enables $M$. minutiflora to arrive and establish under less 267 suitable conditions than $U$. decumbens, with the subsequent formation of dense monospecific 268 patches and the patchy spatial structure observed here. As our MC1 models were designed to 269 incorporate small-scale dispersal, the few significant scales observed for $U$. decumbens may 270 indicate that it relies more on local dispersal to surrounding favorable sites, resulting in a more 271 homogeneous spatial pattern with larger and more spread-out patches, possibly due to its 272 producing comparatively fewer and heavier seeds (Gardener et al. 1993) and being less stress- 
273 tolerant (Xavier et al. 2017). The larger scales of spatial pattern up to 30 to $75 \mathrm{~m}$ for native 274 graminoids may be related to factors such as woody vegetation and fire severity, which may be 275 spatially structured on scales up to $60 \mathrm{~m}$ or more in the cerrado (Gonçalves and Batalha 2011; 276 Dodonov et al. 2014b).

277 We found few relationships with edges or topography, and these were not consistent among sites. 278 The effects of elevation may be related to soil water availability, as water table depth and soil 279 water availability vary with topography in Itirapina (Leite et al, 2018; Xavier et al, 2017). 280 Elevation effects on spatial patterns and invasion success are often complex and depend on 281 interactions with other environmental factors (Davis et al. 2015; Chudomelová et al. 2017). The 282 lack of edge influence was surprising, as previous studies detected effects of linear disturbances 283 on adjacent savanna vegetation (Smit and Asner 2012; Dodonov et al. 2013, 2017; Krix et al. 284 2017). Roads and other linear corridors may facilitate the dispersal of invasive (Gelbard and 285 Belnap 2003; Penone et al. 2012) and native (Suárez-Esteban et al. 2013; Dodonov et al. 2014a) 286 species. However, firebreaks in our study area had little vehicle movement, reducing the 287 dispersal of invasive plants. Edge influence in some studies could have resulted in part from 288 small-scale dispersal, which was incorporated into our MC1 modelos.

289 Negative effects of $M$. minutiflora on native species, such as we observed for graminoids at 290 scales of 10-30 m, are well-known (Almeida-Neto et al. 2010; Hoffmann and Haridasan 2008). 291 Similar negative correlations have been observed for $U$. decumbens in our study and as a 292 decreased abundance of native graminoids at edges dominated by $U$. decumbens by Dodonov et 293 al. (2013). Still, these negative effects were not observed at all the scales evaluated, indicating 294 that the effects of invasive species are generally scale-dependent (Powell et al, 2011; Pauchard 295 and Shea, 2006).

296 Positive relationships between the two invasive species were more common than negative ones, 297 which may reflect similar environmental requirements (e.g. low canopy cover). By hampering 298 the establishment and growth of woody species (Hoffman and Haridasan 2008), these may 299 species favor each other by decreasing overall shading. Positive interactions between co300 occurring invasive species may enable their long-term persistence to the detriment of native 301 species (Simberloff and Von Holle 1999; Vitousek and Walker 1989). However, typical 302 competitive interactions may also be observed (Belote and Weltzin 2006; Xavier and D'Antonio 
303 2017). Our results show that, regardless of the mechanism, negative interaction between invasive 304 grasses may take place at smaller scales than positive ones.

305 Overall, we found that vegetation type was the best predictor of the cover of invasive and native 306 graminoids, whereas elevation and edges had only minor roles. In addition, much of the variation 307 could be explained by fine-scale autocorrelation, as incorporated into our MC1 models. Cerrado 308 graminoid communities appeared to be structured at scales of approx. 20-70 m, with interactions 309 between invasive and native graminoids occurring on similar scales. However, U. decumbens 310 had negative effects at larger scales than the more patchily distributed M. minutiflora and thus 311 the interaction between different invasive grasses may be scale-dependent. As both invasive 312 species were not limited to edges, control and monitoring actions must consider the entire area 313 where these grasses may occur: even if control of invasive grasses in a patch is successful, the 314 existence of other nearby patches is likely to enable reinvasion. Because complete eradication of 315 an invasive species is rarely feasible once this species is well-established and considering that the 316 effects of invasive grasses on native ones occur at different scales, management actions may be 317 directed towards scales at which these effects are strongest. This management has to be species318 specific. Because M. minutiflora had effects at smaller scales than $U$. decumbens, we recommend 319 controlling, even small patches of M. minutiflora when possible, but focusing on larger patches 320 for managing $U$. decumbens. Spatial scales must be considered in studies on the impacts of an 321 control invasive grasses.

\section{Acknowledgments}

325 We thank Cinthya Santos, Viviane Pereira, Carolline Fieker and others for help with fieldwork; 326 Marco Batalha, Milton Ribeiro, Hugo Sarmento, Marcus Cianciaruso, Tadeu Barros, Luciano 327 Lopes, and two anonymous reviewers for suggestions to previous versions of this manuscript; 328 José Eduardo dos Santos and Marcelo Nivert for information on the study sites; and Juliana 329 Santos for help with the map. PD was financed by the Brazilian National Council for Scientific 330 and Technological Development (CNPq grant 141623/2011-0), the Canadian Department of 331 Foreign Affairs and International Trade via the Emerging Leaders in the Americas Program 
332 (ELAP), and the Brazilian Coordination for the Improvement of Higher Education Personnel 333 (Capes). DMSM was financed by CNPq (307839/2014-1).

\section{Supplementary material}

$335 \quad$ Online Resource 1: Pseudocode for the MC1 null models.

$336 \quad$ Online Resource 2: Datasets used for the analyses.

$337 \quad$ Online Resource 3: R code used for the analyses.

\section{References}

339 Almeida-Neto M, Prado PI, Kubota U, Bariani JM, Aguirre, GH, Lewinsohn, TM (2010)

$340 \quad$ Invasive grasses and native Asteraceae in Brazilian Cerrado. Plant Ecol 209: 109-122.

341 Ashton IW, Symstad AJ, Davis CJ, Swanson DJ 2016 Preserving prairies: understanding 342 temporal and spatial patterns of invasive annual bromes in the Northern Great Plains. $343 \quad$ Ecosphere 7: e01438.

344 Augustine, DJ (2003) Spatial heterogeneity in the herbaceous layer of a semi-arid savanna $345 \quad$ ecosystem. Plant Ecology 167: 319-332.

346 Bacaro G, Maccherini S, Chiarucci A, Jentsch A, Rocchini D, Torri D, Gioria M, Tordoni E, 347 Martellos S, Altobelli A, Otto R, Escudero CG, Fernández-Lugo S, Fernández-Palacios 348 JM, Arévalo JR (2015) Distributional patterns of endemic, native and alien species along 349 a roadside elevation gradient in Tenerife, Canary Islands. Community Ecology 16: 223350234.

351 Baruch Z, Jackson R (2005) Responses of tropical native and invader C4 grasses to water stress, 352 clipping and increased atmospheric CO2 concentration. Oecologia 145: 522-532. doi: $353 \quad 10.1007 / \mathrm{s} 00442-005-0153-\mathrm{x}$.

354 Belote RT, Weltzin JF (2006) Interactions between two co-dominant, invasive plants in the 355 understory of a temperate deciduous forest. Biol Invasions 8: 1629-1641. doi: $356 \quad$ 10.1007/s10530-005-3932-8.

357 Chapman JI, Myers AL, Burky AJ, McEwan W (2015) Edge effects, invasion, and the spatial 358 pattern of herb-layer biodiversity in an old-growth deciduous forest fragment. Nat Areas 359 Journal 35: 439-451.

360 Chesson P (2000) Mechanisms of maintenance of species diversity. Annu Rev Ecol Syst 31: 34336166.

362 Chudomelová M, Zelený D, Li CF (2017) Contrasting patterns of fine-scale herb layer species 363 composition in temperate forests. Acta Oecologica 80:24-31.

364 Cilliers SS, Williams NSG, Barnard FJ (2008) Patterns of invasive plant invasions in fragmented 365 urban and rural grasslands across continents. Landscape Ecol 23: 1243-1256.

366 Constantine, W. and Percival, D. 2012. Wavelet methods for time series analysis. R package 367 version 1.1-1. Available from http://CRAN.R-project.org/package=wmtsa

368 Coutinho LM (1978) O conceito de cerrado. Revista Brasileira de Botânica 1: 17-23.

369 D'Antonio CM, Vitousek PM (1992) Biological invasions by exotic grasses, the grass/fire cycle, $370 \quad$ and global change. Annu Rev Ecol Syst 23: 63-87. 
371 D'Antonio CM, Hughes RF, Tunison JT (2011) Long-term impacts of invasive grasses and 372 subsequent fire in seasonally dry Hawaiian woodlands. Ecological Applications 21:16173731628.

374 Dale MRT, Mah M (1998) The use of wavelets for spatial pattern analysis in ecology. J Veg Sci 375 9: 805-814.

376 Dale MRT (1999) Spatial pattern analysis in plant ecology. Cambridge Univ. Press.

377 Dantas VL, Batalha MA (2011) Vegetation structure: fine scale relationships with soil in a $378 \quad$ cerrado site. Flora 206: 341-346.

379 Davis MA, Anderson MD, Bock-Brownstein L, Staudenmaier A, Suliteanu M, Wareham A, 380 Dosch JJ (2015) Little evidence of native and non-native species influencing one 381 another's abundance and distribution in the herb layer of an oak woodland. Journal of 382 Vegetation Science 26:1005-1012.

383 Dias-Filho MB, Carvalho CJR (2000). Physiological and morphological responces of Brachiaria $384 \quad$ spp. to flooding. Pesquisa Agropecuária Brasileira 35(10): 1959-1966.

385 Dodonov P, Harper KA, Silva-Matos DM (2013) The role of edge contrast and forest structure in 386 edge influence: vegetation and microclimate at edges in the Brazilian cerrado. Plant Ecol 387 214: 1345-1359.

388 Dodonov P, Silva DM, Rosatti NB (2014a). Understorey vegetation gradient in a Eucalyptus 389 grandis plantation between a savanna and a semideciduous forest. N Z J ForSci 44: 10.

390 Dodonov P, Xavier RO, Tiberio FCS, Lucena, IC, Zanelli CB, Silva-Matos DM (2014b) Driving 391 factors of small-scale variability in a savanna plant population after a fire. Acta 392 Oecologica 56: 47-55.

393 Dodonov P (2015) Assessment of edge influence in heterogeous vegetation using spatial pattern $394 \quad$ analysis. PhD thesis, Federal University of São Carlos, Brazil.

395 Dong X, Nyren P, Patton B, Nyren A, Richardson J, Maresca T (2008) Wavelets for agriculture 396 and biology: a tutorial with applications and outlook. BioScience 58: 445-453.

397 Durrett R, Levin S (1998) Spatial Aspects of Interspecific Competition. Theoretical Population 398 Biology 53: 30-43.

399

400 Fortin MJ, Jacquez GM (2000) Randomization tests and spatially auto-correlated data. Bulletin 401 of the Ecological Society of America 81: 201-205.

402 Fushita AT, Santos JE, Rocha YT, Zanin EM (2017) Historical land use/cover changes and the 403 hemeroby levels of a bio-cultural landscape: past, present and future. Journal of $404 \quad$ Geographic Information System 9: 576-590.

405 Gardener C, McIvor J, Jansen A (1993) Passage of legume and grass seeds through the digestive 406 tract of cattle and their survival in faeces. Journal of Applied Ecology 30: 63-74

407 Gelbard JL, Belnap J (2003) Roads as conduits for invasive plant invasions in a semiarid 408 landscape. Cons. Biol. 17: 420-432.

409 Gibson DJ, Hulbert LC (1987). Effects of fire, topography and year-to-year climatic variation on $410 \quad$ species composition in tallgrass prairie. Vegetatio 72(3): 175-185.

411 Gonçalves CS, Batalha MA (2011) Towards testing the "honeycomb rippling model" in cerrado. $412 \quad$ Brazilian Journal of Biology 71: 1-8.

413 Harper KA, Lavallee AA, Dodonov P (2018) Patterns of shrub abundance and relationships with 414 other plant types within the forest-tundra ecotone in northern Canada. Arctic Science 4: 415 691-709. 
416 Hassell MP, Comins HN, May RM (1994) Species coexistence and self-organizing spatial 417 dynamics. Nature 370: 290. doi: 10.1038/370290a0.

418 Hoffmann WA, Haridasan M (2008) The invasive grass, Melinis minutiflora, inhibits tree 419 regeneration in a Neotropical savanna. Austral Ecol 33: 29-36.

420 Hoffmann WA, Jaconis SY, McKinley KL, Geiger EL, Gotsch SG, Franco AC (2012) Fuels or 421 microclimate? Understanding the drivers of fire feedbacks at savanna-forest boundaries. $422 \quad$ Austral Ecol 37: 634-643.

423 Hudgins L, Huang J (1996) Bivariate wavelet analysis of Asia Monsoon and ENSO. Adv Atm 424 Sci 13: 299-312.

425 James PMA, Fleming RA, Fortin MJ 2010 Identifying significant scale-specific spatial 426 boundaries using wavelets and null models: spruce budworm defoliation in Ontario, $427 \quad$ Canada as a case study. Landscape Ecology 25: 873-887.

428 Jeltsch F, Milton SJ, Dean WRJ, Rooyen N, Moloney KA (1998) Modelling the impact of small429 scale heterogeneities on tree grass coexistence in semi-arid savannas. Journal of Ecology 430 86:780-793.

431 Kauffman JB, Cummings DL, Ward DE (1994) Relationships of fire, biomass and nutrient 432 dynamics along a vegetation gradient in the Brazilian cerrado. J Ecol 82: 519-531.

433 Klink CA, Joly CA (1989) Identification and distribution of C3 and C4 grasses in open and 434 shaded habitats in Sao Paulo State, Brazil. Biotropica 21: 30-34.

435 Krix DW, Hingee MC, Martin LJ, Phillips ML, Murray BR (2017) Ecological impacts of fire 436 trails on plant assemblages in edge habitat adjacent to trails. Fire Ecology 13: 95-119.

437 LaPaix R, Harper K, Freedman B (2012) Patterns of invasive plants in relation to anthropogenic $438 \quad$ edges within urban forest remnants. App Veg Sci 15: 525-535.

439 Leite MB, Xavier RO, Oliveira PTS, Silva FKG, Silva-Matos DMS (2018) Groundwater depth as 440 a constraint on the woody cover in a Neotropical Savanna. Plant and Soil, 1-15.

441 Liao H, D'Antonio CM, Chen B, Huang Q, Peng S (2016) How much do phenotypic plasticity 442 and local genetic variation contribute to phenotypic divergences along environmental 443 gradients in widespread invasive plants? A meta-analysis. Oikos 125: 905-917. doi: $444 \quad$ 10.1111/oik.02372.

445 MacDonald GR (2004) Cogongrass (Imperata cylindrica) - biology, ecology, and management. $446 \quad$ Crit Rev Plant Sci 23: 367-380.

447 Manly BFJ (2007) Randomizations, bootstrap and Monte Carlo methods in biology. 3 ed. $448 \quad$ Chapman and Hall/CRC.

449 Martins CR, Hay JDV, Carmona R (2009) Invasion potential of two cultivars of Melinis 450 minutiflora in the Brazilian cerrado - seed characteristics and seedling establishment. 451 Revista Árvore 33:713-722.

452 Mendonça AH, Russo C, Melo AC, Durigan, G (2015) Edge effects in savanna fragments: a case $453 \quad$ study in the cerrado. Plant Ecology \& Diversity, 8(4), 493-503.

454 Oliveira FF, Batalha MA (2005) Lognormal abundance distribution of woody species in a 455 cerrado fragment (São Carlos, southeastern Brazil). Revista Brasileira de Botânica 28: 456 39-45.

457 Pauchard A, Shea K (2006) Integrating the study of non-native plant invasions across spatial $458 \quad$ scales. Biol Invasions 8: 399-413.

459 Percival DB, Walden AT (2000) Wavelet methods for time series analysis. Cambridge Univ. $460 \quad$ Press. 
461 Penone C, Machon N, Julliard R, Le Viol I (2012) Do railway edges provide functional 462 connectivity for plant communities in an urban context? Biological Conservation 148: 463 126-133.

464 Petrovskaya N, Petrovskii S, Zhang W (2017) Patch, not patchy, or how much patchy? 465 Classification of spatial patterns appearing in a model of biological invasion. Math Model $466 \quad$ Nat Phenom 12: 208-225.

467 Pivello VR, Carvalho VMC, Lopes PF, Peccinini AA, Rosso S (1999a) Abundance and 468 distribution of native and alien grasses in a "cerrado" (Brazilian savanna) ecological 469 reserve. Biotropica 31: 71-82.

470 Pivello VR, Shida CN, Meirelles ST (1999b) Alien grasses in Brazilian savannas: a threat to the 471 biodiversity. BiodivConserv 8: 1281-1294.

472 Powell KI, Chase JM, Knight TM (2011) A synthesis of plant invasion effects on biodiversity 473 across spatial scales. American Journal of Botany 98: 539-548.

474 R Core Team (2015) R: A language and environment for statistical computing. R Foundation for $475 \quad$ Statistical Computing, Vienna, Austria. https://www.R-project.org/.

476 Reis CM, Zanchetta D (2006) Plano de manejo integrado das Unidades de Itirapina. Secretaria 477 do Meio Ambiente, São Paulo.

478 Ribeiro JF, Walter BMT (2008) As principais fitofisionomias do bioma cerrado. In: Sano, S. S., 479 Almeida, S. P. and Ribeiro, J. F. Cerrado: ecologia e flora. Embrapa, pp. 151-212.

480 Rosenberg MS, Anderson CD (2011) PASSaGE: Pattern Analysis, Spatial Statistics and $481 \quad$ Geographic Exegesis. Version 2. User mannual. Met EcolEvol 2: 229-232.

482 Rouyer T, Fromentin, JM, Stenseth, NC, Cazelles, B (2008) Analysing multiple time scales and 483 extending significance testing in wavelet analysis. Mar EcolProg Series 359: 11-23.

484 Ruggiero PGC, Batalha MA, Pivello VR, Meirelles ST (2002) Soil-vegetation relationships in 485 cerrado (Brazilian savanna) and semideciduous forest, Southeastern Brazil. Plant Ecol 486 160: 1-16.

487 Rossiter-Rachor NA, Setterfield SA, Douglas MM, Hutley LB, Cook GD, Schmidt S (2009) 488 Invasive Andropogon gayanus (gamba grass) is an ecosystem transformer of nitrogen 489 relations in Australian savanna. Ecol Appl 19(6): 1546-1560.

490 Scholes RJ, Archer SR (1997) Tree-Grass Interactions in Savannas." Annu Rev Ecol Syst 28: 491 517-544.

492 Shields JM, Jenkins M, Saunders MR, Zhang H, Jenkins LH, Parks AM (2015) Age distribution 493 and spatial patterning of an invasive shrub in secondary hardwood forests. For Sci 60: 494 830-840.

495 Simberloff D, Von Holle B (1999). Positive Interactions of Nonindigenous Species: Invasional $496 \quad$ Meltdown? Biol Invasions 1: 21-32. doi: 10.1023/a:1010086329619.

497 Smit IPJ, Asner GP (2012) Roads increase woody cover under varying geological rainfall and 498 fire regimes in African savanna. J Arid Envir 80: 74-80.

499 Snyder RE, Chesson P (2003) Local dispersal can facilitate coexistence in the presence of 500 permanent spatial heterogeneity. Ecology Letters 6: 301-9.

501 Stoll P, Prati D (2001) Intraspecific aggregation alters competitive interactions in experimental $502 \quad$ plant communities. Ecology 82(2): 319-327.

503 Strand EK, Robinson AP, Bunting SP (2007) Spatial patterns on the sagebrush steppe/Western $504 \quad$ juniper ecotone. Plant Ecology 190: 159-173.

505 Suárez-Esteban A, Delibes M, Fedriani JM (2013) Unpaved road verges as hotspots of fleshy506 fruited shrub recruitment and establishment. Biological Conservation 167: 50-56. 
507 Tilman D (1994) Competition and Biodiversity in Spatially Structured Habitats. Ecology 75: 2$508 \quad$ 16. doi: $10.2307 / 1939377$.

509 Tilman D (1997) Community invasibililty, recruitment limitation, and grassland biodiversity. $510 \quad$ Ecology 78: 81-92. doi: 10.1890/0012-9658(1997)078[0081:cirlag]2.0.co;2.

511 Travis JMJ, Park KJ (2004) Spatial structure and the control of invasive alien species. Animal $512 \quad$ Conservation 7: 321-330. doi: 10.1017/s1367943004001507.

513 Vitousek PM, Walker LR (1989) Biological Invasion by Myrica Faya in Hawai'i: Plant 514 Demography, Nitrogen Fixation, Ecosystem Effects. Ecological Monographs 59: 247515 265. doi: $10.2307 / 1942601$.

516 Wiegand K, Ward D, Saltz, D (2005) Multi-scale patterns and bush encroachment in an arid 517 savanna with a shallow soil layer. J Veg Sci 16: 311-320.

518 Williams D, Z Baruch (2000) African Grass Invasion in the Americas: Ecosystem Consequences $519 \quad$ and the Role of Ecophysiology. Biological Invasions 2:123-140.

520 Wood SN (2011) Fast stable restricted maximum likelihood and marginal likelihood estimation 521 of semiparametric generalized linear models. Journal of the Royal Statistical Society (B) 522 73(1):3-36.

523 Xavier RO, Leite MB, Silva-Matos DM (2017) Stress responses of native and exotic grasses in a 524 Neotropical savanna predict impacts of global change on invasion spread. Austral $525 \quad$ Ecology 42(5): 562-576.

526 Xavier RO, D'Antonio CM (2017). Multiple ecological strategies explain the distribution of 527 exotic and native C4 grasses in heterogeneous early successional sites in Hawai'i. Journal $528 \quad$ of Plant Ecology 10(3): 426-439.

529 Xavier R O, Leite MB, Silva-Matos DM (2019) Phenological and reproductive traits and their 530 response to environmental variation differ among native and invasive grasses in a $531 \quad$ Neotropical savanna. Biol Invasions. doi: 10.1007/s10530-019-02013-w

532 Xiaobing D, Maarel E (1997) Transect-based patch size frequency analysis. Journal of $533 \quad$ Vegetation Science 8:865-872.

534 Zuur A, Ieno EN, Walker N, Saveliev AA, Smith GM (2009) Mixed efects models and 535 extensions in ecology with R. Springer Science \& Business Media. 


\section{Tables}

538 Table 1. Land uses and vegetation types along the two study transects in São Carlos and 539 Itirapina. The length and elevation is indicated for each section of different land use or plant 540 community.

\begin{tabular}{|c|c|c|c|}
\hline $\begin{array}{l}\text { Section } \\
\text { number }\end{array}$ & $\begin{array}{l}\text { Land use or } \\
\text { vegetation type }\end{array}$ & Length (m) & $\begin{array}{l}\text { Mean elevation (m a.s.l.) (range in } \\
\text { parentheses) }\end{array}$ \\
\hline \multicolumn{4}{|c|}{ Itirapina (I1) } \\
\hline 1 & Railroad & 12 & 704 (704-704) \\
\hline 2 & $\begin{array}{l}\text { Degraded campo } \\
\text { sujo }\end{array}$ & 107 & 702 (700-705) \\
\hline 3 & Firebreak & 13 & $700(700-700)$ \\
\hline 4 & Campo sujo & 287 & 697 (693-700) \\
\hline 5 & Firebreak & 12 & 693 (693-693) \\
\hline 6 & Ecotone & 31 & 692 (692-693) \\
\hline 7 & Forest & 135 & 691 (690-692) \\
\hline 8 & Ecotone & 31 & 693 (691-694) \\
\hline 9 & Campo sujo & 40 & 695 (694-696) \\
\hline 10 & Firebreak & 14 & 696 (696-696) \\
\hline 11 & Campo sujo & 52 & 696 (696-697) \\
\hline
\end{tabular}

São Carlos 1 (S1)

\begin{tabular}{llcc}
\hline 1 & $\begin{array}{l}\text { Degraded campo } \\
\text { sujo }\end{array}$ & 32 & $853(852-854)$ \\
\hline 2 & Firebreak & 3 & $854(854-854)$ \\
\hline 3 & $\begin{array}{l}\text { Degraded campo } \\
\text { sujo }\end{array}$ & 69 & $857(854-860)$ \\
\end{tabular}




\begin{tabular}{|c|c|c|c|}
\hline 4 & Firebreak & 4 & 860 (860-861) \\
\hline 5 & Typical cerrado & 223 & 865 (861-870) \\
\hline 6 & Firebreak & 5 & $870(870-870)$ \\
\hline 7 & $\begin{array}{l}\text { Typical cerrado } \\
\text { (intermediate } \\
\text { regeneration) }\end{array}$ & 209 & 874 (869-877) \\
\hline 8 & Firebreak & 4 & $876(876-876)$ \\
\hline 9 & $\begin{array}{l}\text { Typical cerrado } \\
\text { (intermediate } \\
\text { regeneration) }\end{array}$ & 779 & 873 (862-879) \\
\hline 10 & Firebreak & 6 & $862(862-862)$ \\
\hline \multicolumn{4}{|c|}{ São Carlos 2 (S2) } \\
\hline 1 & Firebreak & 8 & 864 (864-864) \\
\hline 2 & $\begin{array}{l}\text { Typical cerrado } \\
\text { (intermediate } \\
\text { regeneration) }\end{array}$ & 47 & $863(863-864)$ \\
\hline 3 & Firebreak & 6 & $863(863-863)$ \\
\hline 4 & Typical cerrado & 9 & 863 (863-863) \\
\hline 5 & Firebreak & 5 & 863 (863-863) \\
\hline 6 & Ecotone & 39 & 863 (862-863) \\
\hline 7 & Forest & 124 & 859 (857-862) \\
\hline 8 & Typical cerrado & 57 & 862 (859-864) \\
\hline 9 & Firebreak & 6 & 865 (864-865) \\
\hline
\end{tabular}

$541 *$ Railroad: a railroad on the border of the Itirapina study site; firebreak: a dirt road with almost 542 no vegetation

543 
545 Table 2. Frequency (\% quadrats) of the different graminoids in each vegetation type along the 546 three transects. The first value is the observed frequency and the numbers in parentheses are 95\% 547 confidence intervals for the null hypothesis of no difference among the vegetation types. Values 548 outside the confidence interval were considered significantly different from the null model and 549 are underlined.

\begin{tabular}{|c|c|c|c|c|}
\hline & $\begin{array}{l}\text { Urochloa } \\
\text { decumbens }\end{array}$ & $\begin{array}{l}\text { Melinis } \\
\text { minutiflora }\end{array}$ & Native grasses & Native sedges \\
\hline Itirapina I1 & & & & \\
\hline Degraded campo sujo & $97.2(0.9-55.1)$ & $4.7(0-10.3)$ & $\underline{25.2}(36.4-83.2)$ & $9.3(8.4-28)$ \\
\hline Campo sujo & $8.4(7.4-37.7)$ & $4.5(0.8-6.6)$ & $\underline{85.5}(47.5-72.6)$ & $16.1(12.7-23)$ \\
\hline Ecotone & $0(0-62.9)$ & $0(0-12.9)$ & 87.1 (29 - 88.7) & $\underline{35.5}(6.5-32.3)$ \\
\hline Forest & $\underline{0.7}(1.5-51.9)$ & $0(0-9.6)$ & $\underline{7.4}(39.3-80)$ & $16.3(9.6-26.7)$ \\
\hline São Carlos S1 & & & & \\
\hline Degraded campo sujo & $\underline{77.2}(5.9-39.6)$ & $59.4(26.7-65.3)$ & $\underline{54.5}(57.4-86.1)$ & $\underline{0}(5.9-28.7)$ \\
\hline $\begin{array}{l}\text { Typical cerrado } \\
\text { (intermediate regeneration) }\end{array}$ & $\underline{13.3}(14.3-25.7)$ & $42.3(39.4-51.4)$ & $\underline{77.9}(68.1-77.2)$ & $\underline{21.1}(12.8-20)$ \\
\hline $\begin{array}{l}\text { Typical cerrado } \\
\text { (intermediate regeneration) }\end{array}$ & $22.9(9.4-32.3)$ & $57(32.7-58.3)$ & $64.1(62.8-82.1)$ & $\underline{4}(9.4-24.2)$ \\
\hline São Carlos S2 & & & & \\
\hline $\begin{array}{l}\text { Typical cerrado } \\
\text { (intermediate regeneration) }\end{array}$ & $17(0-23.4)$ & $36.2(4.3-55.3)$ & $59.6(17-70.2)$ & $2.1(0-34)$ \\
\hline Typical cerrado & $10.6(0-19.7)$ & $\underline{57.6}(7.6-50)$ & $48.5(21.2-65.2)$ & $18.2(0-28.8)$ \\
\hline Ecotone & $7.7(0-23.1)$ & $46.2(2.6$ - 59) & $15.4(15.4-74.4)$ & $15.4(0-35.9)$ \\
\hline Forest & $\underline{0}(1.6-16.1)$ & $\underline{0}(12.1-43.5)$ & $45.2(25-59.7)$ & $6.5(0.8-23.4)$ \\
\hline
\end{tabular}


551 Table 3. Average cover (\%) of the different graminoids in each vegetation type along the three 552 transects. The first value is the observed cover and the numbers in parentheses are 95\% 553 confidence intervals for the null hypothesis of no difference among the vegetation types. Values 554 outside the confidence interval were considered significantly different from the null model and 555 are underlined.

\begin{tabular}{|c|c|c|c|c|}
\hline & $\begin{array}{c}\text { Urochloa } \\
\text { decumbens }\end{array}$ & Melinis minutiflora & Native grasses & Native sedges \\
\hline \multicolumn{5}{|l|}{ Itirapina I1 } \\
\hline Degraded campo sujo & $61.4(6.3-66.4)$ & $6.3(0-37.5)$ & $\underline{9}(24.3-52.1)$ & $23.1(9.1-29.3)$ \\
\hline Campo sujo & $\begin{array}{l}\underline{28.1} \\
59.9)\end{array}(31.1-$ & $18.4(6.3-24.6)$ & $41.4(31.9-46.4)$ & $16.5(12.6-23.4)$ \\
\hline Ecotone & $0(0-69.1)$ & $0(0-37.5)$ & $51.3(19.8-55.3)$ & $32.7(7-34.4)$ \\
\hline Forest & $6.3(6.3-65.4)$ & $0(0-31.3)$ & $\underline{8.8}(26.4-50.8)$ & $\underline{8.8}(9.9-28.6)$ \\
\hline \multicolumn{5}{|l|}{ São Carlos S1 } \\
\hline Degraded campo sujo & $\underline{52}(6.3-51.1)$ & $41.4(16.6-43.5)$ & $\underline{42.2}(15.9-30.9)$ & $0(6.3-19.2)$ \\
\hline $\begin{array}{l}\text { Typical cerrado } \\
\text { (intermediate } \\
\text { regeneration) }\end{array}$ & $\underline{23.3}(24-38.4)$ & $27.7(25.4-33.9)$ & $23.2(20.9-25.7)$ & $11.3(9-13.5)$ \\
\hline Typical cerrado & $24(15.1-45.1)$ & $31.1(20.6$ - 38.6) & $\underline{16.7}(18.4-28.5)$ & $9.7(7-16.4)$ \\
\hline São Carlos S2 & & & & \\
\hline $\begin{array}{l}\text { Typical cerrado } \\
\text { (intermediate } \\
\text { regeneration) }\end{array}$ & $16.4(0-62.5)$ & $19.9(6.3-33.7)$ & $22.5(6.3-32.2)$ & $37.5(0-57.2)$ \\
\hline Typical cerrado & $10.7(0-49)$ & $15.1(6.3-31.8)$ & $17.4(8.5-30.4)$ & $45.8(0-57.5)$ \\
\hline Ecotone & $10.4(0-62.5)$ & $10.1(6.3-35)$ & $6.3(6.3-33.3)$ & $15.6(0-57)$ \\
\hline Forest & $\underline{0}(6.3-37.5)$ & $\underline{0}(7.3-26.9)$ & $19.5(10.5-27)$ & $7.8(6.3-53.4)$ \\
\hline
\end{tabular}


557 Table 4. Significant scales (m) of spatial pattern for the different graminoid types for the 558 vegetation types along each transect up to a maximum scale of $75 \mathrm{~m}^{*}$. Significance was 559 asssessed via Markov Chain models controlling for differences among the vegetation types. 560 Results for transect S2 are not shown because there were no significant scales of spatial pattern.

Urochloa
decumbens $\quad$ Melinis minutiflora Native grasses $\quad$ Native sedges

Itirapina I1

Overall (entire transect) ns

Degraded campo sujo $\quad 44-58$

Campo sujo

ns

ns

43-75

ns

Ecotone

$\mathrm{N} / \mathrm{A}^{* *}$

Forest

ns

ns

ns

17-31

ns

ns

34-39

São Carlos S1

Overall (entire transect) ns

Degraded campo sujo

10-13, 41-51

43-75

28-75

33-48

Typical cerrado

ns

16-17, 44-51

ns

N/A

(intermediate

51-75

23-75

30-51

regeneration)

Typical cerrado

ns

18, 39-63

ns

ns

561 * The maximum scales assessed were smaller for some sections either because they were on the

562 limit of transect or because they were too short to make the assessment of larger scales

563 meaningful: transect I1, ecotone (62 m) and invaded grassland (58 m); transect S1, invaded

564 grassland (51 m); transect S2, regenerating cerrado (26 m), cerrado (34 m) and ecotone (39 m).

$565^{* *}$ N/A: this species was absent from this vegetation type. 
566 Table 5. Spatial scales at which there were negative relationships between invasive grasses (U. 567 decumbens and M. minutiflora) and native grasses and sedges, up to a maximum scale of $75 \mathrm{~m} *$ 568 Significance was assessed via a first-order Markov chain model controlling for differences 569 between vegetation types. The ecotone and forest in I1 and forest in S2 were not included 570 because the invasive species were absent or nearly absent in these environments.

\begin{tabular}{|c|c|c|c|c|}
\hline & $\begin{array}{l}\text { U. decumbens } \\
\text { vs. Native } \\
\text { grasses }\end{array}$ & $\begin{array}{l}\text { U. decumbens vs. } \\
\text { Native sedges }\end{array}$ & $\begin{array}{l}\text { M. minutiflora vs. } \\
\text { Native grasses }\end{array}$ & $\begin{array}{l}\text { M. minutiflora vs. } \\
\text { Native sedges }\end{array}$ \\
\hline \multicolumn{5}{|l|}{ Itirapina I1 } \\
\hline Overall (entire transect) & 1 & 1 & $5-18$ & $26-44$ \\
\hline Degraded campo sujo & $1,55-58$ & $1,14-22$ & ns & ns \\
\hline Campo sujo & ns & 2 & $5-18$ & $25-46$ \\
\hline \multicolumn{5}{|l|}{ São Carlos S1 } \\
\hline Overall (entire transect) & 1, 7-11, 28-66 & ns & $1-12$ & $23-33$ \\
\hline Degraded campo sujo & $5-13,31-51$ & ns & $34-51$ & $\mathrm{~N} / \mathrm{A}^{* *}$ \\
\hline $\begin{array}{l}\text { Typical cerrado } \\
\text { (intermediate } \\
\text { regeneration) }\end{array}$ & $36-55$ & ns & $1-16$ & $23-34$ \\
\hline Typical cerrado & ns & $69-75$ & $1-3,36-66$ & ns \\
\hline São Carlos S2 & & & & \\
\hline Overall (entire transect) & $19-29$ & ns & ns & $2-4$ \\
\hline $\begin{array}{l}\text { Typical cerrado } \\
\text { (intermediate } \\
\text { regeneration) }\end{array}$ & ns & ns & ns & ns \\
\hline Typical cerrado & ns & ns & $6-9$ & $1-4$ \\
\hline Ecotone & $21-25$ & $11-12$ & $4-10$ & ns \\
\hline
\end{tabular}

571 * The maximum scales assessed were smaller for some sections either because they were on the 572 limit of transect or because they were too short to make the assessment of larger scales 573 meaningful: transect I1, ecotone $(62 \mathrm{~m})$ and invaded grassland $(58 \mathrm{~m})$; transect $\mathrm{S} 1$, invaded 574 grassland (51 m); transect S2, regenerating cerrado (26 m), cerrado (34 m) and ecotone (39 m).

$575 * *$ Native sedges were absent from this vegetation type along this transect. 
577 Table 6. Scales at which there were significantly positive or negative relationships between the 578 two invasive grasses (U. decumbens and M. minutiflora).

\begin{tabular}{|c|c|c|}
\hline & Negative relationship & Positive relationship \\
\hline \multicolumn{3}{|l|}{ Itirapina I1 } \\
\hline Overall (entire transect) & ns & 75 \\
\hline Degraded campo sujo & ns & ns \\
\hline Campo sujo & ns & $66-75$ \\
\hline \multicolumn{3}{|l|}{ São Carlos S1 } \\
\hline Overall (entire transect) & $1-2,12-18$ & ns \\
\hline Degraded campo sujo & $1-2,12-18$ & $41-51$ \\
\hline $\begin{array}{l}\text { Typical cerrado (intermediate } \\
\text { regeneration) }\end{array}$ & 1 & ns \\
\hline Typical cerrado & ns & ns \\
\hline \multicolumn{3}{|l|}{ São Carlos S2 } \\
\hline Overall (entire transect) & ns & ns \\
\hline $\begin{array}{l}\text { Typical cerrado (intermediate } \\
\text { regeneration) }\end{array}$ & ns & ns \\
\hline Typical cerrado & ns & ns \\
\hline Ecotone & ns & $2-10$ \\
\hline
\end{tabular}

579

580 


\section{Figure captions}

582 Fig. 1 Location of the study sites (a) and of the transects sampled therein (b), altimetric profiles 583 (in meters above sea level - $\mathrm{m}$ a. s. l) of the three transects (c), and a schematic representation of 584 the transect I1, showing the different vegetation types and the linear disturbances (darker lines) 585 (d). In C, the black line represents elevation and the background colors show the land use or 586 vegetation type: white for linear disturbances (firebreaks and railroad) and shades of gray 587 representing, from lighter to darker, campo sujo, typical cerrado, ecotone, and forest (Table 1). 588 Satellite images were obtained with the OpenLayers plugin in Quantum GIS software and the 589 schematic representation used drawings from Open Clip Art. Figure widths in C) are proportional 590 to the transect lengths.

591 Fig. 2 Examples of the vegetation types examined in this study: a) degraded campo sujo at 592 transect I1, b) degraded campo sujo at transect S1, c) campo sujo at transect I1, d) typical 593 cerrado (intermediate regeneration) at transect S1, e) typical cerrado at transect S1, f) ecotone at 594 transect I1, g) ecotone at transect S2, h) riparian forest at transect S2. The areas in a) and b) are 595 mostly occupied by invasive grasses, whereas native grasses predominate in the campo sujo in 596 c).

597 Fig. 3 Cover of Urochloa decumbens, Melinis minutiflora, native grasses and native sedges 598 along the three study transects. The background colors show the land use or vegetation type: 599 white for linear disturbances (firebreaks and railroad) and shades of gray representing, from 600 lighter to darker, campo sujo, typical cerrado, ecotone, and forest (Table 1). Figure widths are 601 proportional to transect lengths.

602 Fig. 4 Effects of elevation on the cover of native grasses at transect I1 (a; p=0.012), Urochloa 603 decumbens at transect S1 (b; $\mathrm{p}=0.011$ ), and native grasses at transect S2 (c; p=0.060), and effects 604 of distance to edge on native sedges at transect S1 (d; $p=0.0010)$ and native grasses at transect S2 605 (e; $\mathrm{p}=0.078$ ). The lines correspond to generalized additive models for different vegetation types, 606 which were controlled for in the analysis.

607

608

609 
a)
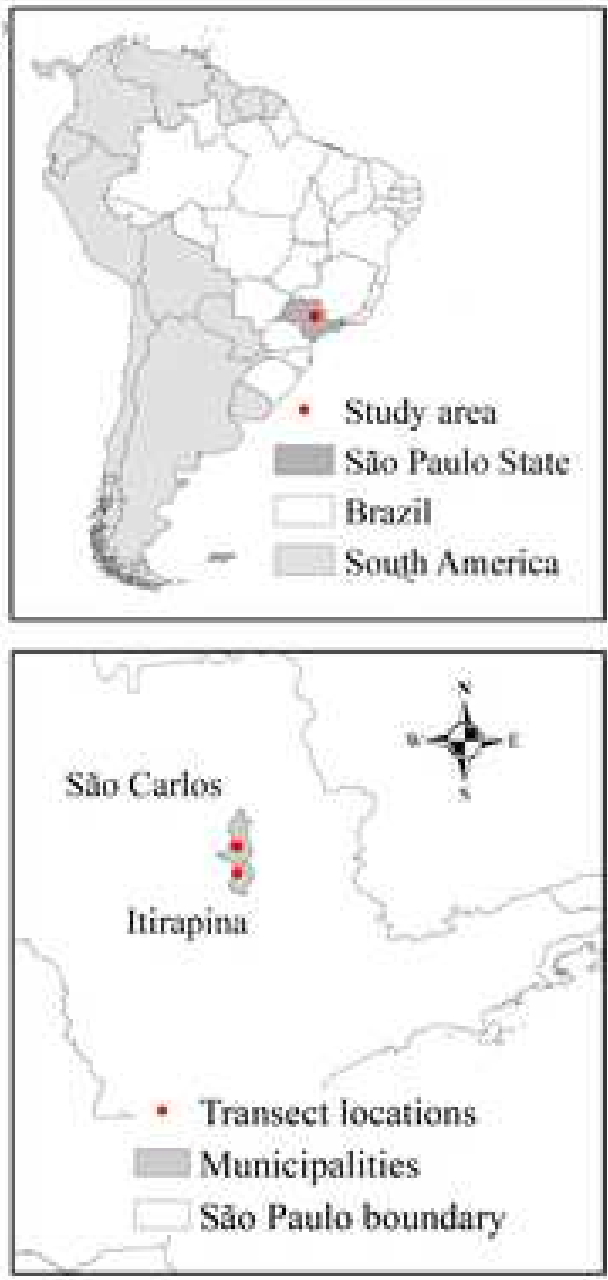

c)

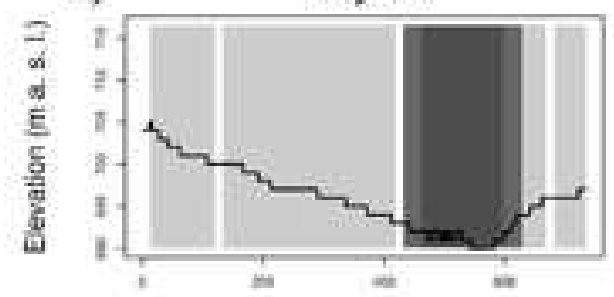

d)
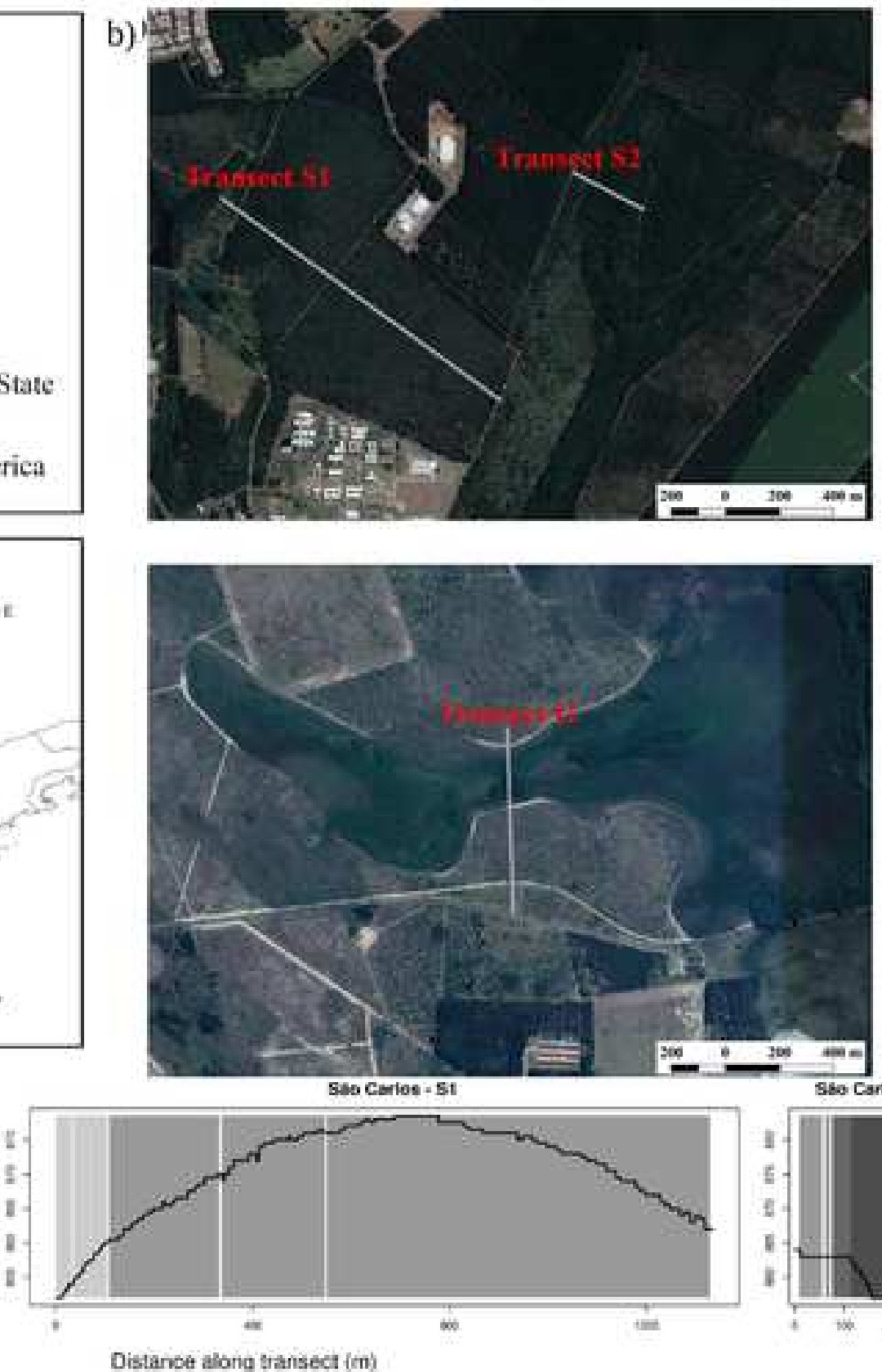

Sbo Carlos * $\$ 2$

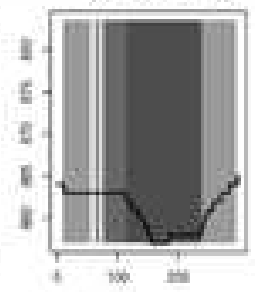

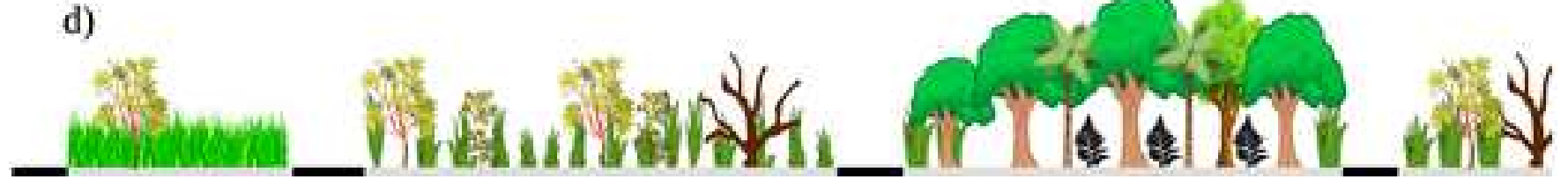




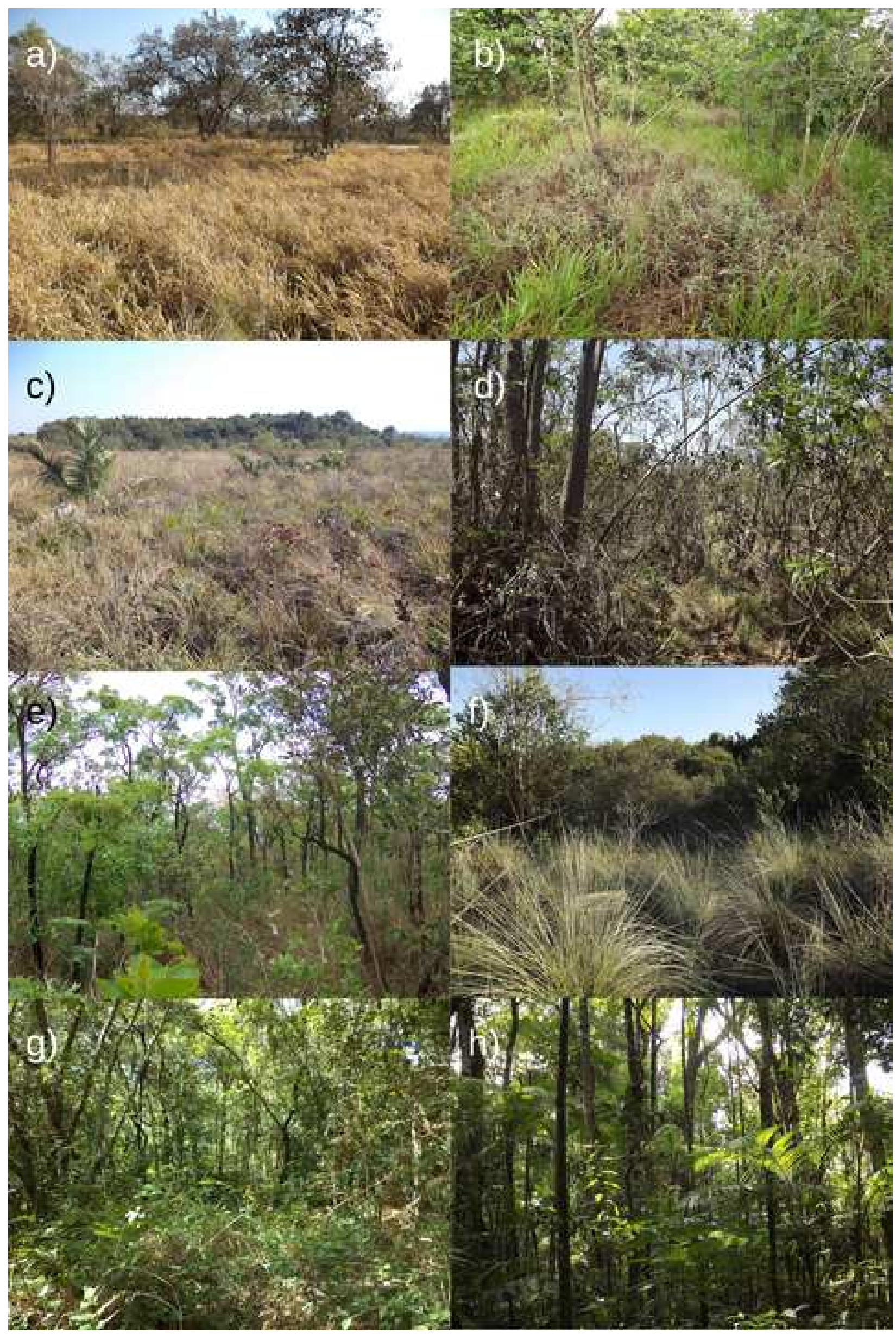


Itirapina - |1
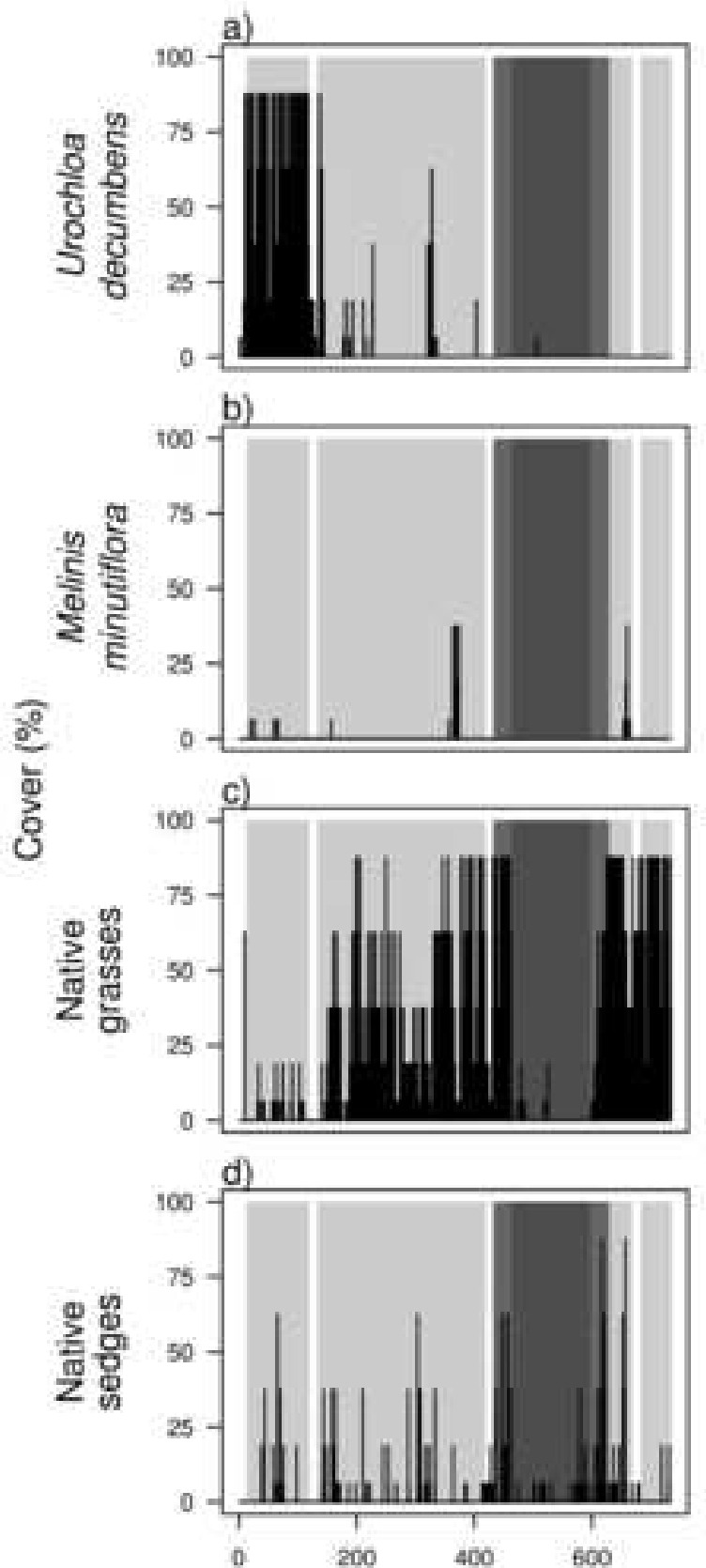

São Caríos - S1

e)
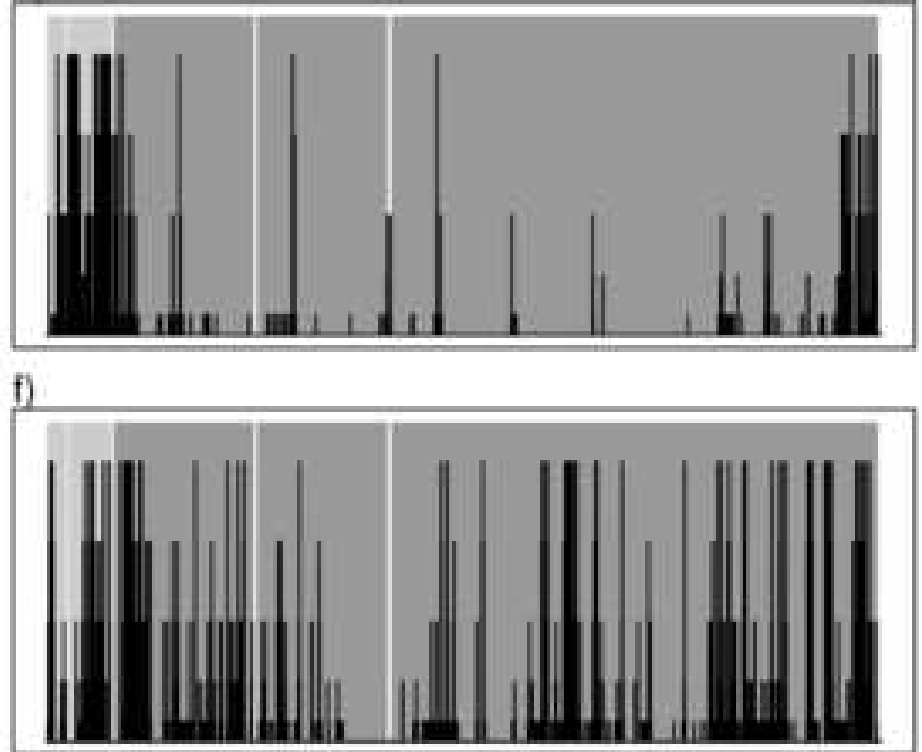

g)

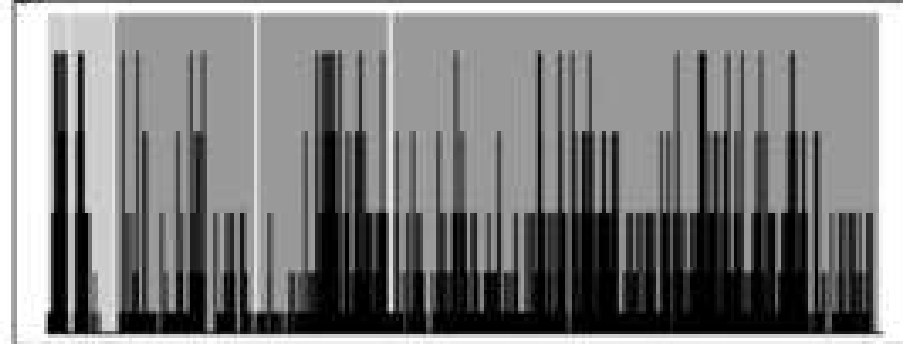

h)

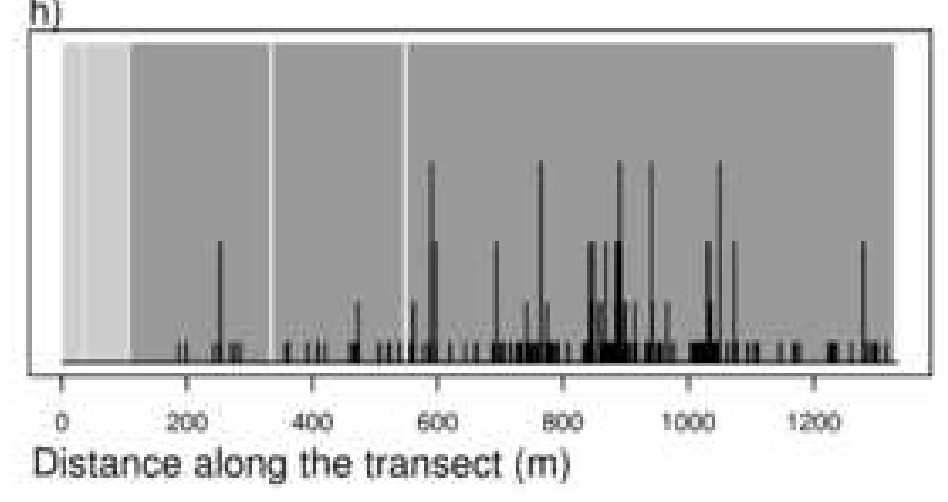

São Carlos - S2
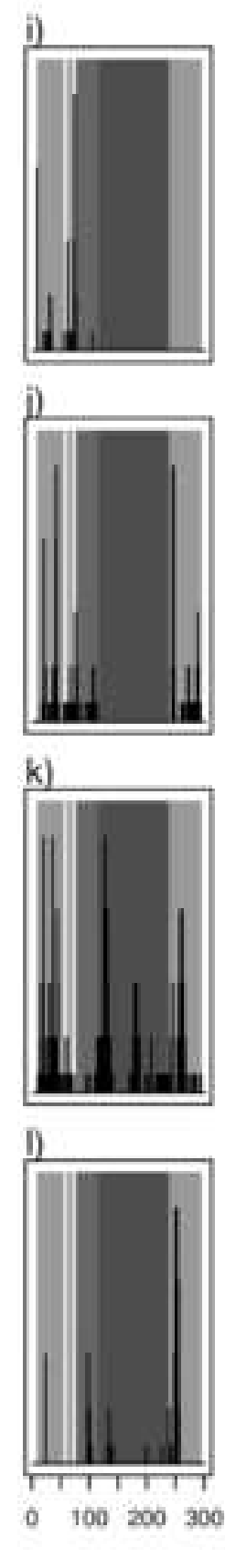
a. Native grasses - I1

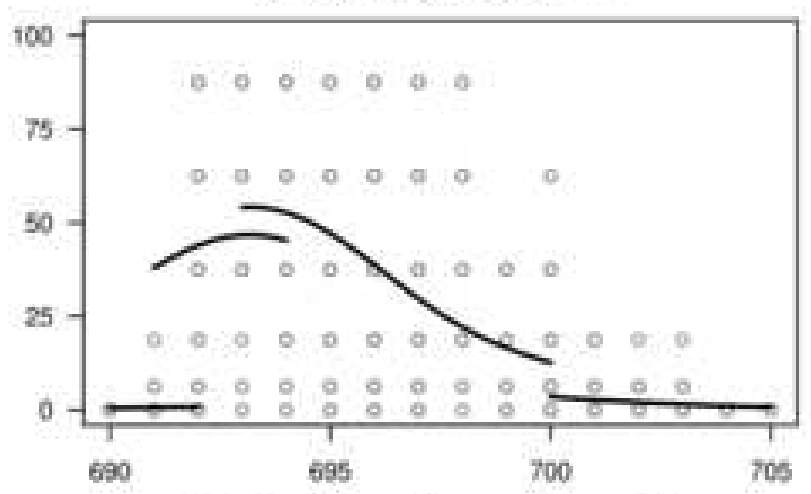

b. Urochioa decumbens - S1
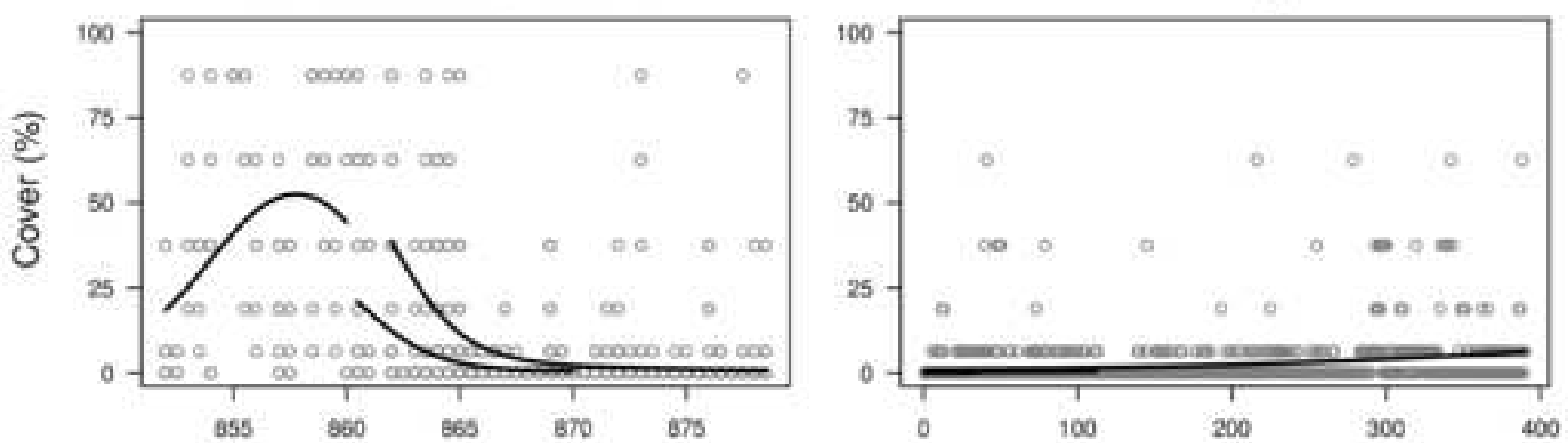

c. Native grasses - S2

e. Native grasses - S2

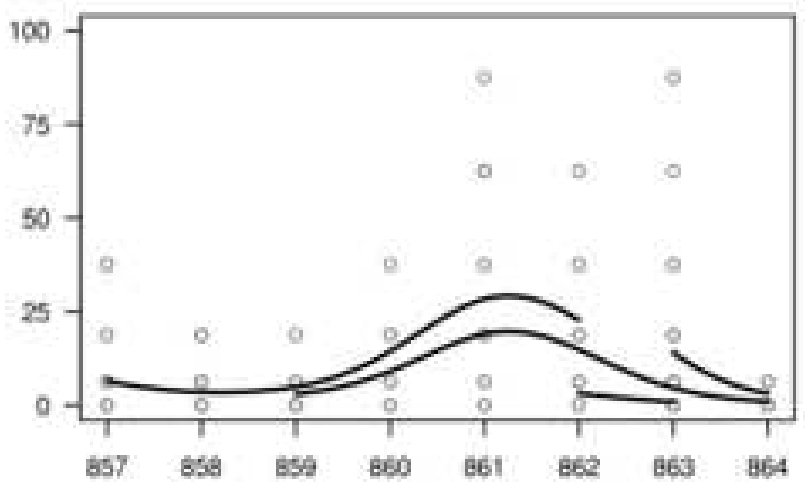

Elevation (m a. s. I.)

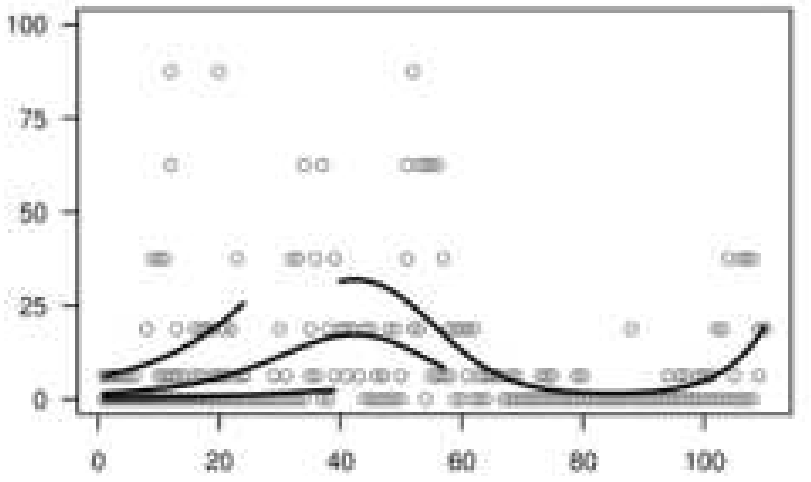

Distance to firebreak (m) 